\title{
Znaczenie agencji oceniających (ratingowych) po wprowadzeniu w 2004 roku przez Komitet Bazylejski Nowej Umowy Kapitałowej
}

\section{Wstęp}

Jednym $\mathrm{z}$ najważniejszych ośrodków opracowujących regulacje w dziedzinie bezpieczeństwa kapitałowego banków jest Bazylejski Komitet ds. Nadzoru Bankowego. Nie ma on mocy prawodawczej, ale jego zalecenia sa wykorzystywane w systemach prawnych wielu krajów. W czerwcu 2004 r., po trwającym pięć lat okresie konsultacji i przygotowań, Komitet Bazylejski opracował dokument pod nazwą Nowe Zasady Adekwatności Kapitałowej (Nowa Umowa Kapitałowa - NUK, Bazylea II), który ma do końca 2007 r. zastapić dotychczasowe rozwiązania normujące obszar adekwatności kapitałowej, wprowadzone Umową Kapitałową z 1988 r. (Bazylea I). Zaproponowane w NUK rozwiązania zostana, podobnie jak wcześniejsze propozycje Komitetu Bazylejskiego, zaimplementowane przez systemy prawne Unii Europejskiej oraz poszczególnych krajów, w tym Polski.

W NUK szczególne znaczenie przypisano zewnętrznym agencjom ratingowym. Na podstawie wydawanych przez nie ocen banki mają dokonywać przypisywania wag ryzyka poszczególnym aktywom $w$ celu wyznaczania współczynnika wypłacalności.

W opracowaniu przedstawiono ogólnie znaczenie agencji ratingowych określone w NUK oraz potencjalne korzyści i zagrożenia wynikające $\mathbf{z}$ wykorzystania przez banki ocen wydawanych przez zewnętrzne instytucje.

\section{Rating i agencje ratingowe}

Rating (ang. credit rating) jest to wyrażona za pomocą symboli niezależna i obiektywna ocena dotycząca wiarygodności kredytowej podmiotu gospodarczego zadłużającego się na rynku finansowym. Wiarygodność kredytowa 
podmiotu definiowana jest przez agencje ratingowe jako prawdopodobieństwo, że podmiot będzie w stanie regulować swoje zobowiązania w terminach i wysokości określonych w umowie. Większej pewności co do możliwości regulowania zobowiązań przez kredytobiorce odpowiadają wyższe oceny [Lipka 1998, s. 370]. W języku polskim jako odpowiednika pojęcia „rating” przez długi czas używano kategorii „ocena wiarygodności kredytowej" [Świderski 1999, s. 131]. Obecnie jednak pojęcie rating jest powszechnie używane w piśmiennictwie fachowym.

Ratingi dostarczają inwestorom niezależnych informacji o wiarygodności kredytobiorcy w postaci umożliwiającej porównywanie ryzyka inwestowania w różne instrumenty finansowe na różnych rynkach. Rating umożliwia też wycenę emisji instrumentów dłużnych. O ile istnieje tylko możliwość sprzedaży papierów wartościowych o znanej ocenie ratingowej, to wycena każdej nowej transzy musi uwzględniać kursy innych papierów wartościowych. Z kolei na nowych rynkach finansowych rating może stać się czynnikiem aktywizującym ich rozwój poprzez upowszechnianie informacji i zwiększanie zaufania inwestorów do emitentów poddających się procedurze uzyskiwania oceny [Lipka 1998, s. 370-372].

Działalność agencji ratingowych ma za zadanie służyć poprawie bezpieczeństwa transakcji zawieranych na rynku finansowym. Wydawane oceny maja niezależny charakter, gdyż agencje oceniające nie są stronami transakcji, a ich wynagrodzenie nie jest uzależnione od osiagnięcia przez emitenta sukcesu w pozyskiwaniu środków finansowych.

\section{Z historii agencji ratingowych w świecie}

Klasyfikowanie instrumentów dłużnych przez specjalne firmy nie jest nowe. Zostało ono zapoczątkowane przez wydawanie ocen dotyczących zdolności kupców do regulowania zobowiązań finansowych przez handlowe agencje informacyjne w połowie XIX wieku. Pierwsza agencja oceniająca handlowców została założona przez Louisa Tappana w Nowym Jorku w 1841 r. Klasyfikacja obligacji została zapoczątkowana przez Johna Moody'ego w 1909 r., który opublikował pierwszy rating obligacji w książce dotyczącej finansowych aspektów działania kolei amerykańskich. Stworzony przez niego kod literowy od Aaa do C służy łatwemu porównywaniu inwestycji i do dziś jest światowym standardem. Popyt na porównywalne oszacowanie ryzyka okazał się bardzo duży, dlatego analizy Johna Moody'ego i skonstruowany przez niego creditrating zostały wykorzystane w ocenie przedsiębiorstw użyteczności publicznej, 
w firmach przemysłowych oraz do oceny walorów emitowanych przez samorządy lokalne [Dziawgo 1998, s. 107-108]. Druga z najważniejszych agencji ratingowych, Standard \& Poor's, powstała w 1941 r.

$\mathrm{Z}$ biegiem lat agencje ratingowe stały się istotnym elementem rynku finansowego Stanów Zjednoczonych. W 1970 r. po raz pierwszy zastosowano ocenę obligacji emitowanych na europejskim rynku finansoywm. Procesy globalizacji przyniosły zwiększenie zainteresowania informacją dotyczącą kondycji finansowej emitentów papierów wartościowych, a oceny nadawane przez instytucje ratingowe zyskały na znaczeniu. Mimo braku formalnego wymogu poddawania się ocenie - rating stał się powszechnym standardem, a w związku ze wzrostem zapotrzebowania na wydawane oceny w ostatnich 30 latach zwiększyła się liczba podmiotów świadczących tego typu usługi [Lipka 1998, s. 373].

\section{Działalność agencji ratingowych w Polsce}

Rating jest stosunkowo nowym zjawiskiem na polskim rynku finansowym. Polska jako kraj uzyskała pierwszy rating od agencji Moody's w 1995 r., co otworzyło droge do pierwszej emisji obligacji polskich na rynku europejskim [Chrabonszczewska, Oręziak 2000, s. 227].

Pierwsza agencja ratingowa w Polsce a zarazem na terenie Europy Środkowo-Wschodniej została utworzona z inicjatywy Związku Banków Polskich. CERA S.A. (Central European Rating Agency), czyli Srodkowoeuropejskie Centrum Ratingu i Analiz, którego udziałowcami zostało 17 dużych polskich instytucji finansowych, podjęło działalność w styczniu 1997 r. [Zawadzka 1999, s. 187]

W 2001 roku większościowy pakiet udziałów CERA S.A. został kupiony przez międzynarodową agencję ratingową Fitch i od listopada $2001 \mathrm{r}$. instytucja ta funkcjonuje pod nazwą Fitch Polska. Jej celem jest wydawanie ocen na potrzeby rynku lokalnego [Polski rating... 2003, s. 12-13]. Fitch Polska jest agencją uniwersalną zajmuje się zarówno oceną podmiotów, jak i instrumentów finansowych. Ocena przez Fitch Polska podmiotów i transakcji jest $z$ góry ograniczona przez rating kraju, co jest powszechną praktyką na rynku międzynarodowym ${ }^{1}$. Działalność agencji Fitch Polska to:

- ratingi $\mathrm{i}$ analizy jednostek samorządowych, firm, instytucji finansowych oraz dłużnych papierów wartościowych,

- publikacja biuletynu „Rating\&Rynek”,

- szczegółowe raporty analityczne dotyczące podmiotów emitujących papiery dłużne oraz innych wybranych instytucji [Zaleska 2002, s. 8].

${ }^{1}$ Ocena podmiotu dokonana przez instytucje ratingowe nie może być wyższa niż rating kraju jako całości. 


\section{Zadania agencji ratingowych po wprowadzeniu Nowej Umowy Kapitałowej}

W czerwcu 2004 r. po wieloletnich międzynarodowych konsultacjach opublikowano ostateczna, zaakceptowaną przez członków Komitetu Bazylejskiego wersję Nowej Umowy Kapitałowej (Bazylea II). Poza uwzględnianymi dotychczas wymogami co do wielkości kapitału $z$ tytułu ryzyka kredytowego i rynkowego, określa ona też wymogi z tytułu ryzyka operacyjnego.

Nowa Umowa Kapitałowa składa się z trzech części - filarów (rys. 1), z których pierwszy, dotyczący minimalnych wymogów kapitałowych, jest zdecydowanie najbardziej rozbudowany. Trzy filary NUK omawiane w dokumentach Komitetu Bazylejskiego powinny być traktowane jako uzupełniające się części ogólnego działania zmierzającego do umocnienia międzynarodowej metodologii oceny adekwatności kapitałowej i poprawy efektywności jej funkcjonowania [Nowa metodologia... 2000, s. 5].

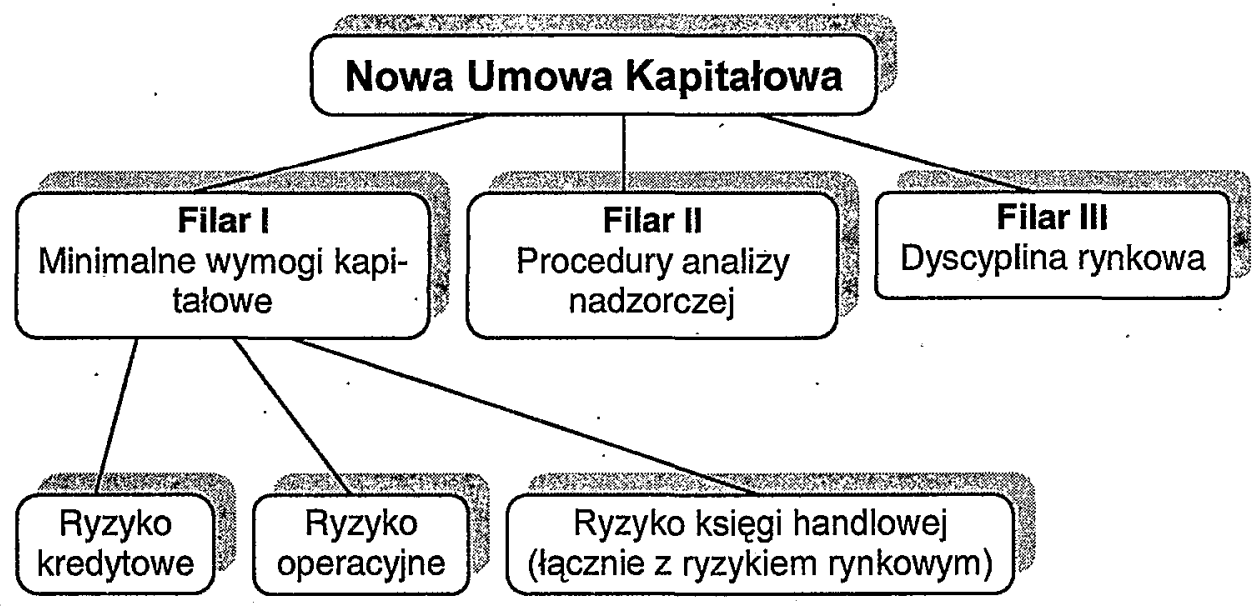

\section{Rysunek 1}

Struktura Nowej Umowy Kapitałowej

Źródło: Opracowanie własne na podstawie: International Convergence... 2004, s. 3.

Minimalne wymogi z tytułu ryzyka kredytowego mogą być wyznaczane na podstawie jednej $\mathrm{z}$ następujących metod:

- metoda standardowa (Standardised Approach - SA), w której przypisane poszczególnym aktywom wagi ryzyka dla celów wyznaczania współczynnika wypłacalności są uzależnione od ratingów nadanych przez zewnętrzne agencje ratingowe, 
- metody oparte na ratingach wewnętrznych banku (Internal Ratings-Based Approach - IRB) w dwóch wersjach: podstawowej (Foundation IRB $F I R B$ ) oraz zaawansowanej (Advanced IRB - AIRB).

Do wyznaczania wymogów kapitałowych z tytułu ryzyka operacyjnego banki mogą wykorzystywać jedną z następujących metod:

- metoda podstawowych wskaźników (Basic Indicator Approach),

- podejście standardowe (Standardised Approach - SA), opracowane przez nadzór bankowy,

- metoda zaawansowanych pomiarów (Advanced Measurement Approaches - $A M A$ ), bazująca na pomiarze ryzyka rynkowego za pomocą modelu wewnętrznego stworzonego przez bank.

Metoda standardowa pomiaru ryzyka kredytowego ma za zadanie zastapić funkcjonującą w ponad 140 krajach metodę zawartą w Umowie Kapitałowej z 1988 r., którą należało zmienić przede wszystkim z uwagi na brak wrażliwości na ryzyko ${ }^{2}$. Najważniejsze modyfikacje zawarte w metodzie standardowej NUK w stosunku do ustaleń z $1988 \mathrm{r}$. polegały na uzależnieniu przyznawanych wag ryzyka od nadanych tym podmiotom ratingów przez uznane zewnętrzne agencje ratingowe [Dziekoński 2003, s. 28]. Wagi ryzyka dla poszczególnych kredytów w Bazylei II wyznaczane są na podstawie kryterium oceny, jaką podmiot otrzymał od agencji oceniającej, a nie - jak w Umowie Kapitałowej z 1988 r. - od warunku przynależności do OECD (tab. 1).

W przypadku kredytów zaciąganych przez banki krajowy nadzór bankowy będzie miał prawo wyboru jednego spośród dwóch. wariantów przyznawania wag ryzyka, przy czym wybrana opcja będzie obowiązywać wszystkie banki podlegające danemu nadzorowi.

Według wariantu I, kredytom zaciaganym przez wszystkie banki w danym kraju zostanie przypisana waga ryzyka o jedną kategorię niższa niż kredytom pobranym przez rządy lub bank centralny kraju, przy czym bankom z krajów o niższych ratingach (od $\mathrm{BB}+$ do $\mathrm{B}-$ ) $\mathrm{i}$ bankom $\mathrm{z}$ krajów nieposiadających ratingu zostanie przyznana waga ryzyka $100 \%$.

Według wariantu II, wagi ryzyka dla kredytów zaciąganych przez banki wyznaczane są na podstawie ratingów nadanych bezpośrednio bankom przez zewnętrzne agencje ratingowe. Banki bez ratingu otrzymują wage ryzyka $50 \%$. W krajach, gdzie nadzór krajowy wybierze tę opcję, będzie możliwe zastosowanie wobec kredytów o krótkoterminowym charakterze (do 3 miesięcy) korzystniejszej kategorii ryzyka, o jedną klasę niżej, nie niższej jednak niż $20 \%$.

\footnotetext{
${ }^{2}$ W Umowie Kapitałowej z 1988 r. współczynnik wyplacalności został określony jako stosunek sumy kapitałów własnych banku do aktywów ważonych ryzykiem. Wagi ryzyka wynosiły $0 \%, 20 \%, 50 \%$ oraz $100 \%$ w zależności od rodzaju należności i od tego, czy podmiot, któremu udzielono kredytu jest zarejestrowany na terenie państwa należącego do OECD.
} 
Rozwiązanie to dotyczy zarówno banków posiadających rating jak i nieposiadających go, ale nie obejmuje banków obciążonych wagą ryzyka $150 \%$ [International Convergence... 2004, s. 17].

\section{Tabela 1}

Wagi ryzyka przyznawane kredytom w Nowej Umowie Kapitałowej w zależności od rodzaju należności i ratingu nadanego kredytobiorcy przez agencję Standard \& Poor's ${ }^{3}(w \%)$

\begin{tabular}{|c|c|c|c|c|c|c|c|}
\hline $\begin{array}{l}\text { Rating kredytobiorcy } \\
\text { Rodzaj należności }\end{array}$ & $\begin{array}{l}\text { AAA do } \\
\text { AA- }\end{array}$ & $\begin{array}{c}A+d o \\
A-\end{array}$ & \begin{tabular}{|c|} 
BBB+ \\
do \\
BBB- \\
\end{tabular} & $\begin{array}{l}\mathrm{BB}+ \\
\text { do } \\
\mathrm{BB}-\end{array}$ & $\begin{array}{c}B+\text { do } \\
B-\end{array}$ & $\begin{array}{l}\text { Poni- } \\
\text { żej B- }\end{array}$ & $\begin{array}{l}\text { Brak } \\
\text { ratin- } \\
\text { gu }\end{array}$ \\
\hline $\begin{array}{l}\text { Należności od rządów cen- } \\
\text { tralnych i banków central- } \\
\text { nych }\end{array}$ & 0 & 20 & 50 & 100 & 100 & 150 & 100 \\
\hline $\begin{array}{l}\text { Należności od banków } \\
\text { (wariant I) }\end{array}$ & 20 & 50 & 100 & 100 & 100 & 150 & 100 \\
\hline $\begin{array}{l}\text { Należności od banków } \\
\text { (wariant II) }\end{array}$ & 20 & 50 & 50 & 100 & 100 & 150 & 50 \\
\hline $\begin{array}{l}\text { Należności krótkotermino- } \\
\text { we (do } 3 \text { m-cy) od banków } \\
\text { (wariant II) }\end{array}$ & 20 & 20 & 20 & 50 & 50 & 150 & 20 \\
\hline $\begin{array}{l}\text { Należności od przedsię- } \\
\text { biorstw (łącznie z ubezpie- } \\
\text { czeniowymi) }\end{array}$ & 20 & 50 & 100 & 100 & 150 & 150 & 100 \\
\hline Należności detaliczne & \multicolumn{7}{|c|}{75} \\
\hline $\begin{array}{l}\text { Należności z tytułu kredy- } \\
\text { tów mieszkaniowych }\end{array}$ & \multicolumn{7}{|c|}{35} \\
\hline
\end{tabular}

Źródło: Opracowanie własne na podstawie: International Convergence... 2004, s. 15-21.

W metodzie standardowej wagi ryzyka przyznawane są na podstawie ocen wydawanych przez uznane zewnętrzne agencje ratingowe. Jeśli dany podmiot ma przyznane przez różne agencje dwie oceny, którym przypisane są różniące się wagi ryzyka, stosuje się ocenę odpowiadającą wyższemu poziomowi ryzyka. Jeżeli podmiot ma przyznane trzy lub więcej ocen, z których wynikają różniące się wagi ryzyka, do określenia odpowiedniej wagi ryzyka wykorzystuje się wyższą z dwóch najniższych [International Convergence... 2004, s. 24].

Komitet Bazylejski określił także warunki, jakie musi spełniać agencja ratingowa, aby mogła być uznana przez nadzór krajowy. Są to następujące warunki:

\footnotetext{
${ }^{3}$ W NUK jako przykłady posłużyły ratingi nadawane przez agencje Standard \& Poor's. Agencja ta przyznaje podmiotom następujące oceny (uszeregowane zgodnie $z$ malejącą oceną wiarygodności kredytowej): AAA, AA, A, BBB, BB, B, CCC, CC, C, D. Ratingi lepsze, od AAA do BBB - określane sq̨ mianem ratingu inwestycyjnego, pozostałe - ratingu spekulacyjnego.
} 
- obiektywność - metoda oceniania musi być odpowiednio sformalizowana, usystematyzowana i możliwa do uzasadnienia na podstawie danych wieloletnich,

- niezależność - zewnętrzna agencja ratingowa powinna być niezależna od politycznych i ekonomicznych nacisków mogących wpływać na wydawaną ocenę,

- międzynarodowa dostepność i przejrzystość - uzyskanie oceny powinno być dostępne dla krajowych i zagranicznych instytucji na takich samych warunkach,

- jawność - metodologia oceny przez agencję ratingową powinna być dostępna,

- odpowiednie zasoby do dziatania agencji ratingowej - wiedza, bazy danych, systemy informatyczne dla zapewnienia wysokiej jakości ocen,

- wiarygodność - miejsce w rynku udzielonych ratingów; częstość korzystania przez różne podmioty $\mathrm{z}$ usług firmy ratingowej [International Convergence... 2004, s. 23].

\section{Pozytywne i negatywne aspekty przyznawania wag ryzyka w Nowej Umowie Kapitałowej na podstawie ocen zewnętrznych agencji ratingowych}

Uzależnienie poziomu ryzyka kredytów w Nowej Umowie Kapitałowej od oceny agencji ratingowych może budzić wątpliwości z kilku ẇzględów. W większości krajów poza Europą Zachodnią i Stanami Zjednoczonymi udział podmiotów gospodarczych posiadających zewnętrzne ratingi jest niewielki, a działalność tych agencji nie jest $w$ pełni uregulowana. Agencje ratingowe często obniżają oceny podmiotu dopiero po zgłoszeniu przez niego pogorszenia kondycji zamiast robić to $z$ wyprzedzeniem. Potwierdzają to na przykład wysokie ratingi krajów, w których wkrótce po przyznaniu wysokiej oceny wystapiły zjawiska kryzysowe [Jaworski, Zawadzka 2001, s. 81].

Uzależnienie wag ryzyka od nadanych ratingów spowoduje związanie wysokości współczynnika wypłacalności ${ }^{4}$ banku z oceną wydawaną przez komercyjną instytucję. Sztucznie utworzony monopol wrażliwych na naciski prywatnych przedsiębiorstw (agencji ratingowych) może nie sprostać postawionemu

\footnotetext{
${ }^{4}$ Współczynnik wypłacalności określony jest jako stosunek kapitałów własnych banku do aktywów ważonych ryzykiem. Banki zobowiązane są do utrzymywania współczynnika wypłacalności na poziomie co najmniej $8 \%$.
} 
zadaniu, jakim jest lepsze dostosowanie wielkości kapitału w bankach do ponoszonego przez nie ryzyka [Bonnat, Legras 2000, s. 8].

W związku z uzależnieniem wymogów co do wielkości kapitału od oceny agencji ratingowych mogą pojawić się trudności w planowaniu wielkości kapitału w bankach, gdyż obniżenie ratingu może obniżyć współczynnik wypłacalności banku. Ponieważ współczynnik wypłacalności musi być utrzymywany na poziomie co najmniej $8 \%$, banki będa zmuszone do utrzymywania pewnych rezerw kapitału na wypadek możliwości obniżenia oceny kredytowanych jednostek [Iwanicz-Drozdowska 2000, s. 70].

Komitet Bazylejski zaproponował, aby wagi ryzyka były przyznawane na podstawie ocen wydawanych przez uznane agencje ratingowe. Nie jest jednak jednoznaczne, którą agencję będzie można określić jako „uznaną”, a którą nie. Wprowadzenie jednolitego rynku finansowego w Unii Europejskiej pociagnie za sobą stosowanie zasad wzajemnego uznawania. Oznacza to, że jeżeli jakakolwiek agencja zdobędzie uznanie nadzoru w jednym $z$ krajów Unii, to automatycznie stanie się ona uznawaną agencją w pozostałych krajach.

Większość przedsiębiorstw o najlepszych ratingach (AA - lub wyższych) funkcjonuje w Stanach Zjednoczonych i prawdopodobnie tamten rynek, w przeciwieństwie do pozostałych krajów, odniesie największe korzyści z tytułu znacznego zredukowania wymogów kapitałowych [Bonnat, Legras 2000, s. 8]. Przyjmując, zgodnie z założeniami Komitetu Bazylejskiego, że na skutek wprowadzenia NUK ilość kapitału w skali globalnej nie zmieni się, zwiększone koszty poniosą banki działające w krajach słabiej rozwiniętych gospodarczo.

Wprowadzenie kilku przedziałów ryzyka nie wiąże dostatecznie faktycznie ponoszonego ryzyka z przypisywanymi wagami ryzyka. Niewielka liczba wag ryzyka uwzględnianych $\mathrm{w}$ metodzie standardowej NUK sprawia, że dużego znaczenia nabiera tzw. efekt progu [Bonnat, Legras 2000, s. 10]. Prawdopodobieństwo niewywiązywania się ze zobowiązań finansowych podmiotów o różnych ratingach dokonanych na podstawie oszacowań agencji Standard \& Poor's różni się znacznie od prawdopodobieństwa niewywiązywania się ze zobowiązań ocenionego na podstawie przyznanych $w$ metodzie standardowej NUK wag ryzyka ${ }^{5}$ (rys. 2 ).

Ryzyko kredytowania jest przeszacowywane dla przedsiębiorstw najlepszych (o ratingach od AAA do BBB-) i niedoszacowywane dla przedsiębiorstw najgorszych (o ratingach poniżej BBB-).

\footnotetext{
${ }^{5}$ Ponieważ wspólczynnik wypłacalności definiowany jako stosunek sumy kapitałów własnych do aktywów ważonych ryzykiem musi wynosić przynajmniej $8 \%$, to wadze ryzyka $50 \%$ odpowiada prawdopodobieństwo niewywiązywania się ze zobowiązań równe $4 \%$, wadze ryzyka $100 \%$ odpowiada prawdopodobieństwo $8 \%$ itd.
} 
Przedsiębiorstwa $z$ oceną ratignową $\mathrm{BBB}$ oraz $\mathrm{BB}$ wedhug metody standardowej NUK mają przypisaną taką samą wagę ryzyka (8\%). Wedhug oszacowania dokonanego przez agencję S\&P's, ryzyko to różni się prawie czterokrotnie (rys. 2). W perspektywie jednorocznej wynosi od 0,37\% dla BBB do $1,36 \%$ dla $\mathrm{BB}$, a w pięcioletniej od $3,41 \%$ dla $\mathrm{BBB}$ do $12,38 \%$ dla BB. Dla przedsiębiorstw o ratingach gorszych niż CCC nawet w krótkim czasie ryzyko jest niedoszacowane (według S\&P's, $30,85 \%$ na 1 rok i $53 \%$ na 5 lat wobec $12 \%$ według metody standardowej NUK). W przypadku przedsiębiorstw o najgorszych ocenach wiarygodności kredytowej rozbieżności będąjeszcze większe.

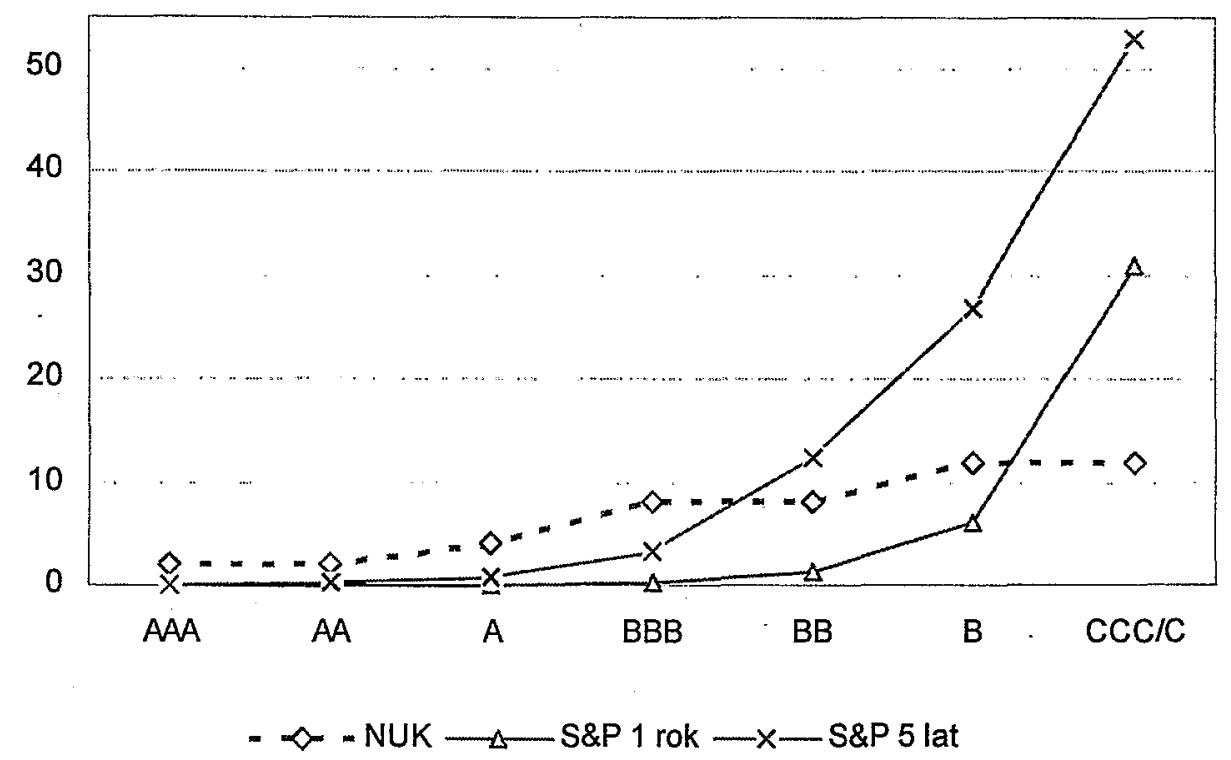

\section{Rysunek 2}

Prawdopodobieństwo niewywiązania się ze splaty kredytów przedsiębiorstw według ocen agencji Standard and Poor's oraz zgodnie z metodą standardową Nowej Umowy Kapitalowej ( $w \%)$

Źródło: Opracowanie własne na podstawie: International Convergence... 2004, s. 19 oraz EU 2003 Annual... 2004, s. 10.

W literaturze przedmiotu zwraca się też uwagę na zagrożenie stosowania wag ryzyka wyznaczanych na podstawie ocen agencji ratingowych, jakim jest procykliczność. Przyznane podmiotom ratingi są uzależnione nie tylko od siły ekonomicznej podmiotu, ale też od warunków zewnętrznych, m.in. od fazy cyklu koniunkturalnego. W sytuacji wywołanego spadkiem koniunktury gospodarczej pogorszenia się przyznawanych kredytobiorcom ratingów banki 
odnotują podniesienie wymogów kapitałowych. Wzrost wymogów kapitałowych będzie natomiast skutkował zwiększeniem kosztów kredytu powodującym ograniczenie jego dostępności, a tym samym pogłębienie kryzysu w gospodarce [Koleśnik 2004, s. 53].

Poza wymienionymi i wyżej zagrożeniami oparcie wag ryzyka w NUK na niezależnych ocenach agencji ratingowych przyniesie niewątpliwe korzyści. Najważniejszą z korzyści będzie lepsze powiązanie ponoszonego przez bank ryzyka $z$ niezbędnymi wymogami kapitałowymi. Nie należy bowiem zapominać, że według obowiązujących zasad z 1988 r., określanie wag ryzyka przypisywanego poszczególnym kredytom dokonywane jest na podstawie kryterium przynależności do OECD państwa, na którego terenie zarejestrowany jest podmiot zaciagający kredyt. Kryterium to nie spełnia przypisywanej mu funkcji różnicującej. Zgodnie $z$ nim, taką samą wagę ryzyka (0\%) przyznaje się nie tylko kredytom zaciągniętym przez rządy Niemiec, Austrii, Szwajcarii i Wielkiej Brytanii, ale też przez rządy Polski czy Turcji, charakteryzujące się zdecydowanie niższą wiarygodnością kredytowa.

Oparcie wag ryzyka na ocenach niezależnych agencji urealni też koszt kredytu. Pozwoli na obniżenie marży pobieranej od dłużników charakteryzujących się dobrą kondycją finansową i wysoką wiarygodnością kredytowa. Według dotychczasowych rozwiazzan, kredyty udzielane klientom o wysokiej wiarygodności wymagają takiego samego pokrycia kapitałowego jak kredyty udzielane podmiotom o wysokim ryzyku. Sprawia to, że koszt kredytu dla podmiotów o dobrej kondycji finansowej jest zbyt wysoki w stosunku do generowanego przez nie ryzyka dla banku. W konsekwencji występuje tendencja do pozyskiwania środków przez podmioty o wysokiej ocenie wiarygodności kredytowej na rynku pozabankowym.

\section{Podsumowanie}

Wprowadzenie zasad Nowej Umowy Kapitałowej spowoduje, że agencjom ratingowym oraz wydawanym przez nie ocenom zostanie przypisana nowa rola. Poza, jak dotychczas, wydawaniem ocen wiarygodności kredytowej na użytek inwestorów, agencje będą dokonywać oceny służące bankom do takiego określania zakresu podejmowanego ryzyka, by był on odpowiedni do posiadanego kapitału własnego.

Uzależnienie wag ryzyka przyznawanych aktywom, a więc pośrednio poziomu kapitału w bankach od ocen kredytobiorców, spowoduje lepsze dostosowanie kapitału własnego do ponoszonego ryzyka i umożliwi bardziej reali- 
styczną wycenę kosztu kredytu, szczególnie udzielanego podmiotom o dobrej kondycji finansowej.

Powiązanie wielkości kapitału $\mathrm{w}$ bankach $\mathrm{z}$ zewnętrznymi ratingami może też przynieść wiele zagrożeń, m.in.:

- ryzyko nadużywania swojej pozycji przez agencje ratingowe,

- ryzyko ulegania zewnętrznym naciskom przez agencje ratingowe,

- zbyt wolne reakcje agencji ratingowych na zmiany kondycji finansowej ocenianych podmiotów,

- zwiększenie obciążeń banków działających w krajach słabiej rozwiniętych gospodarczo,

- pogłębianie faz cyklu koniunkturalnego (procykliczność).

\section{Literatura}

BENING H. (2002): The road towards Basel 3. "Journal of International Banking Regulation", grudzień.

BONNAT L., LEGRAS J. (2000): The Cooke is dead, long live the Cooke! CCF, Paryż.

CHRABONSZCZEWSKA E., OREZIAK L. (2000): Międzynarodowe rynki finansowe. SGH, Warszawa.

DZIAWGO D. (1998): Credit-rating. Ryzyko i obligacje na międzynarodowym rynku finansowym. PWN, Warszawa.

DZIEKOŃSKI P. (2003): Nowa Bazylejska Umowa Kapitałowa - konsekwencje dla rynku kredytowego. Materiały i Studia NBP, Zeszyt nr 164, Warszawa.

(2004): EU 2003 Annual Default Study \& Rating Transitions, Standard \& Poor's, Nowy Jork.

(2004): International Convergence of Capital Measurement and Capital Standards. A Revised Framework. Basel Committee on Banking Supervision, Bazylea.

IWANICZ-DROZDOWSKA M. (2000): Adekwatność kapitałowa banków według standardów Bazylejskiego Komitetu Nadzoru Bankowego. „Bank i Kredyt”, nr 1-2.

JAWORSKI W., ZAWADZKA Z. (2001): Bankowość. Podręcznik akademicki. Poltext, Warszawa.

KOLEŚNIK J. (2004): Stan prac nad Nową Umową Kapitałową - wyzwania dla polskiego sektora bankowego, „Studia i Prace Kolegium Zarządzania i Finansów”, Zeszyt Naukowy 41, SGH, Warszawa.

LIPKA W. (1998): Rating i jego rola na rynkach finansowych. W: Sławiński A. (red.): Studium bankowości. WIB, Warszawa.

(2000): Nowa metodologia adekwatności kapitałowej - filar 3-dyscyplina rynkowa. NBP, GINB, Warszawa.

(2003): Polski rating w globalnej sieci. „Bank. Miesięcznik finansowy”, nr 1.

ŚWIDERSKI J. (1999): Finanse banku komercyjnego. Biblioteka Menadżera i Bankowca, Warszawa. 
ZALESKA M. (2002): Identyfikacja przez deponentów banków zagrożonych upadłością. „Bank i Kredyt”, nr 8.

ZAWADZKA Z. (1999): Warunki bezpieczeństwa banków i ich klientów. W: Jaworski W. (red.): Banki polskie u progu XXI wieku, Poltext, Warszawa.

\section{The Importance of the Assessment Agencies after Implementation of the New Capital Adequacy Framework by the Basle Committee on Banking Supervision in 2004}

\section{Abstract}

Basle Committee on Banking Supervision published in 2004 the New Capital Adequacy Framework. A special importance is assigned in this document to the external assessment agencies. Banks will have to determine the minimum capital requirements on the basis of assessments by the external agencies.

The role of the external assessment agencies in the New Capital Adequacy Framework and potential threats and benefits from using by banks the external assessments for determination of the minimum capital requirements are presented in the paper. 